\title{
Performance of Wheat in Five Soils of Different Textures under Freshwater and Wastewater Irrigation
}

\author{
Mohammad A. Mojid ${ }^{1}$, Khadija A. Mousumi ${ }^{1} \&$ Tanvir Ahmed ${ }^{1}$ \\ ${ }^{1}$ Department of Irrigation and Water Management, Bangladesh Agricultural University, Mymensingh, 2202, \\ Bangladesh \\ Correspondence: Mohammad A. Mojid, Bangladesh Agricultural University, Mymensingh, Bangladesh. E-mail: \\ ma_mojid@yahoo.com
}

Received: June 27, 2020 Accepted: July 11, 2020 Online Published: July 29, 2020

\begin{abstract}
This study investigated the effects of five soils of different textures on wheat cultivation under irrigation with freshwater (FW) and municipal wastewater (WW). The experimental design was a split-plot with irrigation water quality as main factor and soil texture as sub-factor in three replications. These factors respectively comprised 2 and 5 treatments. Soil texture significantly $(\mathrm{p} \leq 0.05)$ influenced plant height, leaf area index $(\mathrm{LAI})$, spike length, number of grains per spike, above ground dry matter (ADM), grain yield, straw yield and biomass yield of wheat in most cases both under FW and WW irrigation. The harvest index (HI) of wheat responded significantly under FW irrigation only. Under FW, treatment $T_{5}$ (silt loam) produced the highest grain yield $\left(4.2 \mathrm{t} \mathrm{ha}^{-1}\right)$ followed by $\mathrm{T}_{3}$ (loam-1) (3.1 t ha $\left.\mathrm{t}^{-1}\right)$; the lowest yield $\left(2.0 \mathrm{tha}^{-1}\right)$ was in the control treatment, $\mathrm{T}_{1}$ (loamy sand). Under WW, treatment $\mathrm{T}_{2}$ (sandy loam) produced the highest grain yield $\left(5.0 \mathrm{t} \mathrm{ha}^{-1}\right)$ followed by $\mathrm{T}_{4}$ (loam-2) $\left(4.5 \mathrm{tha}^{-1}\right)$ both of which are statistically similar; the lowest yield $\left(3.4 \mathrm{tha}^{-1}\right)$ was in the control treatment. Treatments $\mathrm{T}_{2}$ and $\mathrm{T}_{4}$ provided the highest straw yield $\left(5.6 \mathrm{tha}^{-1}\right)$ and treatment $\mathrm{T}_{2}$ provided the highest biomass yield $\left(10.6 \mathrm{t} \mathrm{ha}^{-1}\right)$, both under WW; both $\mathrm{T}_{2}$ and $\mathrm{T}_{4}$ produced invariant biomass yields. Compared to other treatments, $\mathrm{T}_{2}$ and $\mathrm{T}_{4}$ gave statistically similar but significantly higher water productivity with respect to straw and grain yields. The lowest water productivity was in treatment $T_{1}$ under both water qualities. The results of this study provided sound criteria in selecting suitable lands for wheat cultivation based on irrigation water quality, specifically in alluvial plains where soil texture is prone to high variations. Also, the observed facts of improved productivity of lower quality coarse-textured soils due to addition of easily available and inexpensive clay would provide guidance to bring unproductive sandy soils under production by clay amendments.
\end{abstract}

Keywords: soil texture, water quality, cereal crop, yield response, water uptake, water productivity

\section{Introduction}

Irrigation water is becoming scarce with continuous increase in its demand almost everywhere in the world, especially in areas with intensive agricultural practices. Therefore, effective ways of water conservation and management are of primary importance (Al-Rashed and Sherif, 2000; Rahman et al., 2020). Wastewater (e.g., urban wastewater, industrial wastewater) is an unconventional water source, the availability of which is increasing over time due to increasing use of water by the growing population (van Rooijen et al., 2005). Under water-scarce situations, use of wastewater in irrigation is increasingly getting attention because of its increasing supply together with relatively low cost and growing awareness of environmental quality (Mojid et al., 2010). In case of poor fertility soils, wastewater is an important source of nutrients for crop production (Kiziloglu et al., 2007; Mojid and Wyseure, 2013). However, wastewater irrigation may also be hazardous to environment since it contains pollutants, such as macro- and micro-organic and inorganic matters. These constituents of wastewater may harm environment, health, soil, aquifer and crops (Feigin et al., 1990; US Environmental Protection Agency, 1992). Disposal of urban/municipal wastewater is also a problem of increasing importance throughout the world. Consequently, both the necessity to conserve freshwater and to dispose of wastewater safely and economically makes wastewater use in agriculture a very feasible option (Wang et al., 2007). Irrigation with municipal wastewater may permit a more efficient use of water resources and considerably limit environmental pollution due to its direct disposal into surface water bodies. Wastewater irrigation may be a prime solution in the optimization of water resources in water-scarce areas (Virto et al., 2006). Peri-urban agriculture with municipal wastewater is an emerging agricultural practice in Bangladesh (Mojid et al., 2010) and several other countries in the world. Wastewater reuse can reduce fertilizer rates due to its fertilizer contribution in crop production (Tabriz et al., 2011; Biswas et al., 
2017; Biswas and Mojid, 2018) and thus can provide a low-cost source of irrigation water (Mojid et al., 2012a).

In many countries, most of the suitable lands have already been brought under agriculture, and cultivation now needs spilling over to marginal lands like hilly lands, charlands and other inferior quality lands. For example, the agriculture in Bangladesh is now being expanded in the large charland areas (river shores) of the country where soils are mostly coarse-textured (e.g., sandy soil). But, soil texture is an important control of water regime and nutrient availability for crop production; it influences the physical, chemical and hydraulic properties of soils. Sandy soils, characterized by less than $18 \%$ clay and more than $68 \%$ sand in the top $100 \mathrm{~cm}$ of the soil profile, occur in every part of the world (van Wambeke, 1992). The productivity of such soils is limited due to their low water holding capacities, high infiltration rates, high evaporation, low fertility levels, very low organic matter content (Mojid, et al., 2012b), and excessive deep percolation losses. These unfavorable soil properties cause low water productivity of the crops cultivated in these soils. Consequently, these soils have not received adequate research attention yet although cultivating sandy soils may be a promising intervention to increase food production in many developing countries like Bangladesh. A significant proportion of such land has been remaining unproductive because of its low fertility. Management of these soils through proper reclamation measures to increase crop productivity adds a great deal to interest in a day wherein the available land area for cultivation is declining all the time in Bangladesh and many other countries in the world.

Addition of fine natural deposits, such as clay and bentonite, can increase productivity of sandy soils by eliminating or minimizing constraints associated with these soils. This proposition is specifically suitable in areas where these amendment materials are available naturally in abundance and inexpensive (Al-Omran et al., 2004). Until now, information on the effects of using clay as an amendment for sandy soils on crop yields, specifically wheat yield, under wastewater irrigation are not available. However, soil texture is an important factor to be considered in wastewater irrigation because soil fertility or soil contamination will depend mainly on soil texture. Therefore, a suitable soil texture for irrigated crops is a concern in wastewater irrigation. If wastewater irrigation could be used for keeping soil productivity sustainable, it would reduce water deficit, increase the overall crop production and thereby provide food security in resource-scarce regions, such as Bangladesh. A comprehensive knowledge of the effects of municipal wastewater on the growth and yield of crops in soils of different textures is necessary before recommending irrigation with wastewater. This study was planned to investigate the impact of five soils of different textures on wheat cultivation under irrigation with municipal wastewater in terms of growth and yield attributes of wheat as well as the yield, and to identify suitable soil texture(s) for wheat cultivation under freshwater and wastewater irrigation.

\section{Material and Methods}

\subsection{Experimental Site}

The experiment was done in the central farm of Bangladesh Agricultural University in Mymensingh, Bangladesh $\left(24.75^{\circ} \mathrm{N}\right.$ latitude, $90.50^{\circ} \mathrm{E}$ longitude and $18 \mathrm{~m}$ a.m.s.l.). The average maximum and minimum air temperatures ranged from $22.2^{\circ} \mathrm{C}$ to $30.0^{\circ} \mathrm{C}$ and from $10.7^{\circ} \mathrm{C}$ to $20.0^{\circ} \mathrm{C}$, respectively, over the experimental period (November through March) in three consecutive cropping seasons (2008-09, 2009-10 and 2010-11). The mean relative humidity, pan evaporation and sunshine varied from $74 \%$ to $86 \%, 1.9 \mathrm{~mm}$ to $3.9 \mathrm{~mm}$ and $4.3 \mathrm{~h}$ to $8.4 \mathrm{~h}$, respectively. An amount of 53-mm rainfall (i.e., $41 \mathrm{~mm}$ and $12 \mathrm{~mm}$ in December and February, respectively) was recorded over the 2010-11 cropping season with $50.2 \mathrm{~mm}$ of effective rainfall. No rainfall occurred over crop cycle in the two previous years.

\subsection{Field Plot Preparation}

An area of $14 \mathrm{~m} \times 10 \mathrm{~m}$ was divided into 3 strips each of them being split in 2 blocks. The distance between the adjacent strips was $2 \mathrm{~m}$ and that between the adjacent blocks was $1 \mathrm{~m}$. Each block was split in 5 unit plots of $1 \mathrm{~m}^{2}$ each. Two adjacent unit plots within a block was $1 \mathrm{~m}$ separated. The experimental layout was a split-plot with 10 irrigation water quality and soil texture treatments in 3 replications that gives a total number of 30 plots. In each unit plot, a pit of $60 \mathrm{~cm}$ depth and $1 \mathrm{~m}$ square area was dug manually with a spade. A polyethylene sheet was placed on the four vertical sides of each pit to prevent lateral seepage of water. All the pits were filled with a mixture of loamy sand collected from river shore and field soils at different ratio to obtain the five different soil textures required in each block (Table 1); this table also contained the average bulk density, saturated hydraulic conductivity, organic matter, electrical conductivity (EC) and $\mathrm{pH}$ of the soils. More details on plot preparation are available in the literature (Mojid et al., 2009; Mojid et al., 2012b).

\subsection{Experimental Design and Set-Up}

Three-year historical data involving irrigation experiments were analyzed with the aim to evaluate the interaction 
effects of soil texture and irrigation water quality on wheat cultivation. The experimental design was a split-plot with irrigation water quality as the main factor of two levels and soil texture as sub-factor of 5 levels, which gives 10 treatments in 3 replications (Fig. 1). The water quality was composed of freshwater (FW) obtained from a deep borehole well $\left(\mathrm{I}_{1}\right)$ and wastewater $(\mathrm{WW})$ from municipal sewage of Mymensingh town $\left(\mathrm{I}_{2}\right)$. The soil texture involved loamy sand (control $\left.\mathrm{T}_{1}\right)$, sandy loam $\left(\mathrm{T}_{2}\right)$, loam-1 $\left(\mathrm{T}_{3}\right)$, loam-2 $\left(\mathrm{T}_{4}\right)$ and silt loam $\left(\mathrm{T}_{5}\right)$.

Table 1. Percentage of sand, silt and clay, and textural classes, average bulk density $(\gamma)$, saturated hydraulic conductivity $\left(\mathrm{K}_{\mathrm{sat}}\right)$, organic matter content $(\mathrm{OM})$, electrical conductivity $(\mathrm{EC})$ and $\mathrm{pH}$ of the experimental soils

\begin{tabular}{cccccccccr}
\hline Treatments & \% Sand & \% Silt & \% Clay & $\begin{array}{c}\text { Textural } \\
\text { class }\end{array}$ & $\gamma\left(\mathrm{g} \mathrm{cm}^{-3}\right)$ & $\begin{array}{c}\mathrm{K}_{\text {sat }} \\
\left(\mathrm{cm} \mathrm{h}^{-1}\right)\end{array}$ & $\begin{array}{c}\text { OM } \\
(\%)\end{array}$ & $\begin{array}{c}\mathrm{EC} \\
\left(\mathrm{S} \mathrm{cm}^{-1}\right)\end{array}$ & $\begin{array}{c}\mathrm{pH} \\
\end{array}$ \\
\hline $\mathrm{T}_{1}$ & 79.48 & 14.48 & 6.04 & Loamy sand & 1.41 & 27.36 & 0.39 & 11.4 & 5.99 \\
$\mathrm{~T}_{2}$ & 54.48 & 37.02 & 8.50 & Sandy loam & 1.37 & 1.34 & 0.99 & 14.9 & 5.88 \\
$\mathrm{~T}_{3}$ & 52.72 & 38.24 & 9.04 & Loam-1 & 1.38 & 1.27 & 0.86 & 13.3 & 5.13 \\
$\mathrm{~T}_{4}$ & 41.00 & 49.00 & 10.00 & Loam-2 & 1.36 & 0.67 & 1.34 & 34.1 & 4.88 \\
$\mathrm{~T}_{5}$ & 15.00 & 72.00 & 13.00 & Silt loam & 1.28 & 0.41 & 1.47 & 29.8 & 6.05 \\
\hline
\end{tabular}

Table 2 lists the pertinent chemical constituents of freshwater and wastewater used for irrigating the experimental wheat plots. It is noted that the concentrations of boron, iron, potassium, nitrate nitrogen, phosphate phosphorus, sodium, lead, copper, zinc and cadmium in wastewater were below their threshold values set by Food and Agriculture Organization (FAO) (1992) for safe use in agriculture, except for manganese. Details of the quality parameters of Mymensingh sewage are found in Mojid et al. (2010). Recommended fertilizer doses for wheat $120 \mathrm{~kg} \mathrm{~N}, 32 \mathrm{~kg} \mathrm{P}, 62 \mathrm{~kg} \mathrm{~K}, 20 \mathrm{~kg} \mathrm{~S}, 3 \mathrm{~kg} \mathrm{Zn}$ and $1 \mathrm{~kg} \mathrm{~B}$ per hectare in the form of urea, triple super phosphate, muriate of potash, gypsum, zinc sulphate and borax, respectively - were used. Two-thirds of urea and the entire doses of the other fertilizers were applied as basal dose. The remaining urea was top dressed before applying the first irrigation. Wheat seeds (cv. Shatabdi, @ $120 \mathrm{~kg} \mathrm{ha}^{-1}$ ) were sown at 2-3 cm depth in 20-cm apart rows on 6 December 2008, 6 December 2009 and 24 November 2010. In order to control insect pests, Bavistine (0.9 kg ha $\left.{ }^{1}\right)$ and Ridomil Gold (1 $\left.\mathrm{kg} \mathrm{ha}^{-1}\right)$ were sprayed before first irrigation.

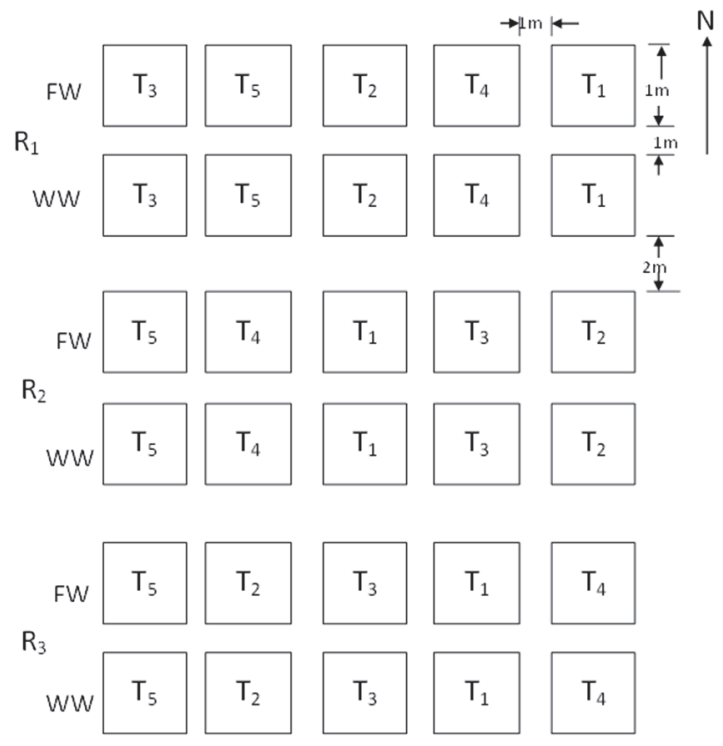

Figure 1. Field layout of the irrigation water quality vs. soil texture experiment executed on the central farm of Bangladesh Agricultural University in Mymensingh, Bangladesh 
Table 2. Chemical constituents of freshwater (FW) and wastewater (WW) used for irrigation of experimental plots of wheat at Bangladesh Agricultural University farm, Mymensingh

\begin{tabular}{cccccc}
\hline Water & \multicolumn{5}{c}{ Chemical constituents $\left(\mathrm{mg} \mathrm{L}^{-1}, \mathrm{dS} \mathrm{m}^{-1}\right.$ for EC) } \\
\cline { 2 - 6 } type & $\mathrm{TN}$ & $\mathrm{P}$ & $\mathrm{K}$ & $\mathrm{EC}$ & $\mathrm{pH}$ \\
\hline FW & $1.52 \pm 0.03$ & $0.039 \pm 0.005$ & $2.35 \pm 0.04$ & $0.385 \pm 0.017$ & $7.08 \pm 0.03$ \\
WW & $18.39 \pm 2.4$ & $4.28 \pm 0.64$ & $13.59 \pm 1.25$ & $1.049 \pm 0.078$ & $7.33 \pm 0.12$ \\
\hline
\end{tabular}

\subsection{Data Recording}

Irrigation was scheduled based on crop-water requirement and observation of soil moisture condition. Because of lighter texture, total four irrigations were applied to treatments $T_{1}$ (loamy sand), $T_{2}$ (sandy loam) and $T_{3}$ (loam-1) compared to treatments $\mathrm{T}_{4}$ (loam-2) and $\mathrm{T}_{5}$ (silt loam) in which total three irrigations were applied. Soil moisture was measured in the plots with a digital soil-moisture meter (DSMM, General Tools and Instruments) before applying irrigation. Leaf area index (LAI) was determined at 75 days after sowing (DAS) on five representative plants collected from each plot with an LI-3100 AREA METER (LI-Cor. Inc. Lincoln. Nebraska, USA). Total area covered by all five plants was calculated from the planting density. By definition, the LAI was calculated as the ratio of leaf area to the covering ground area. The above ground dry matter (ADM) of the crop was also determined at 75 DAS by collecting five representative plants from each plot. The plants were oven-dried at $60^{\circ} \mathrm{C}$ in $72 \mathrm{~h}$ and weighed to determine the ADM. The crop was harvested when the spikes were completely ripened. The harvested crop of each plot was bundled separately and tagged. In order to assess the change in soil moisture status during the growing season, the soil-moisture content of each plot was measured immediately after harvesting. Soil-moisture content data, recorded over time, were used to estimate water used by the crop during the growing season. After harvest, different crop attributes, such as the number of total tillers, effective and non-bearing tillers, plant height, spike length, spikelets per spike and grains per spike for each plot were counted. Plant materials were then air-dried. Threshing, cleaning and drying of grains and straws of each plot were done carefully, grain and straw yields being recorded separately. The harvest index (HI) of wheat was determined by the ratio of grain yield to total biomass yield (grain plus straw yield). The water productivity of wheat, defined as the ratio of yield to total amount of water used, was determined both for grain and biomass yields. Root development of wheat in different treatments was measured at the end of the growing season. Just after harvest, roots over three different soil depths $(0-15,15-30$ and $30-45 \mathrm{~cm})$ were collected separately by sampling soil columns with a representative area of the soil surface. Roots were obtained after careful soil-washing through a plastic net. They were successively air-dried and oven-dried at $60^{\circ} \mathrm{C}$ in $72 \mathrm{~h}$ to obtain their mass. The root-density was calculated by dividing the root dry weight by the covering area. The analysis of variance of data obtained was done by using Statistix 10 software package of Analytical Software (2019). Comparison of means of the plant attributes among the factors and treatments was done using Tukey's HSD test at $5 \%$ level of significance ( $\mathrm{p} \leq 0.05)$.

\section{Results and Discussion}

\subsection{Growth Attributes of Wheat}

Quality of irrigation water affected the plant height, leaf area index, above-ground dry matter and root-density at different depths significantly $(\mathrm{p}<0.05)$ except root density at $30-45 \mathrm{~cm}$ soil layer (Table 3 ). WW $\left(\mathrm{I}_{2}\right)$ produced significantly taller plants and greater LAI and ADM than $\mathrm{FW}\left(\mathrm{I}_{1}\right)$, which produced greater root-density than WW. Texture of the soils did not influence plant height and LAI significantly $(\mathrm{p} \leq 0.05)$ except treatment $\mathrm{T}_{1}$ (Loamy sand, Table 1), which produced significantly shorter plant and smaller LAI than the other treatments (Table 3). Treatment $\mathrm{T}_{3}\left(\right.$ Loam-1, Table 1) produced the tallest plants $(84.6 \mathrm{~cm})$ and $\mathrm{T}_{4}(\mathrm{Loam}-2)$ produced the shortest plants $\left(82.9 \mathrm{~cm}\right.$ ). Treatment $\mathrm{T}_{5}$ (Silt loam) produced the highest LAI and $\mathrm{T}_{1}$ produced the least LAI; in general, LAI increased with the increase in clay content of the soils. Lower saturated hydraulic conductivity of the amended soils $\left(T_{2}-T_{5}\right)$ than the control treatment $\left(T_{1}\right)$ (Table 1) reduced percolation losses of water in the amended treatments. The reduced percolation loss augmented soil-water and nutrient retention with a consequent increase in soil fertility, which enhanced the growth of wheat leaves and, consequently, caused increase in LAI. ADM of wheat increased significantly as texture of the soils became finer except treatment $\mathrm{T}_{5}$, which produced significantly higher ADM than treatment $\mathrm{T}_{1}$ but lower ADM than the other treatments.

Soil texture significantly influenced root-growth at the top $0-15 \mathrm{~cm}$ soil layer; the coarser the texture the higher was the root-density. Most of the roots were obtained in the top $0-15 \mathrm{~cm}$ soil layer; only small fractions of roots were in the lower layers. Soil texture exerted only minimal influence on root-growth at the lower soil layers. The topsoil retained most of the nutrients both from the applied fertilizers and WW and promoted more extensive growth of roots in the upper soil profile compared to the lower one (Table 3). Increased root growth with increasing 
fertilizer was also reported by $\mathrm{Li}$ et al. (2004). The three coarser-textured soils $\left(\mathrm{T}_{1}, \mathrm{~T}_{2}\right.$ and $\left.\mathrm{T}_{3}\right)$ provided significantly higher root-density compared to the two finer-textured soils $\left(\mathrm{T}_{4}\right.$ and $\left.\mathrm{T}_{5}\right)$ (Table 3 ). Lesser amount of irrigation water could be applied in coarser-textured soils with a quicker water loss through percolation and evaporation compared to the finer-textured soils. Consequently, plants in coarse-textured soil (e.g., $\left.\mathrm{T}_{1}\right)$ generally suffered from water stress for a while before each irrigation application. Although irrigation was scheduled based on soil-water status, the allowable soil-water deficit was higher in coarse-textured soils compared to that in finetextured soils. The extensive root system helped the plants to take up more water and nutrients from the soil than did the narrow root system. The plants thus compensated, to some extent, water deficit by increasing water-uptake through additional rooting in coarse-textured soils.

The interaction effects of irrigation water quality and soil texture were significant on the growth attributes in most cases except for the root-density at two lower soil layers, $15-3 \mathrm{~cm}$ and $30-45 \mathrm{~cm}$ (Table 3 ). The plant height ranged from $75.7 \mathrm{~cm}\left(\mathrm{I}_{1} \mathrm{~T}_{1}\right)$ to $89.7 \mathrm{~cm}\left(\mathrm{I}_{2} \mathrm{~T}_{2}\right)$ among different $(10)$ combinations of irrigation water quality and soil texture. Only a few treatment combinations exerted significant effect on LAI. The highest LAI was obtained in $\mathrm{T}_{2}$ under FW irrigation (3.6) and in $\mathrm{T}_{5}$ under WW irrigation (2.7) and the overall lowest LAI in $\mathrm{T}_{1}$ under WW irrigation (1.2). These observations in LAI are in agreement with the findings of Mojid et al. (2012c) who obtained levelingeffects of irrigation water quality when it contained more than $75 \% \mathrm{WW}$; the influence of WW on LAI reached a plateau when irrigation was applied entirely with WW (Fig.5 in Mojid et al., 2012c). The leveling-off of irrigation on LAI occurred due to over-fertilization of wheat with recommended fertilizer doses in combination with fertilizer contribution of WW in their experiments. This effect also occurred in our study in the plots irrigated with WW; with recommended fertilizer doses and fertilizer contribution from WW the plots provide smaller LAI than those under FW irrigation. Most treatment combinations exerted significant effect on ADM. The smallest ADM was in $\mathrm{I}_{1} \mathrm{~T}_{1}$ and largest $\mathrm{ADM}$ in $\mathrm{I}_{2} \mathrm{~T}_{4}$. Table 3 demonstrates that $\mathrm{WW}$ contributed more in increasing plant height and ADM than FW in all five soil textures. The textural effects on plant height and ADM were more systematic under FW than under WW; in general, the coarser the soil the smaller were these plant attributes. The trend of rootgrowth in the top soil layer in relation to irrigation water quality was opposite to that of plant height and ADM. FW in combination with the soil textures produced more roots compared to the combination of WW and soil textures. The interaction of irrigation water quality and soil texture did not reveal any systematic textural effect on root density. Since the root density in the entire root zone was dominated by that in the top layer, the interaction effect of irrigation water quality and soil texture was also similar to that in the top soil layer.

Table 3. Quantity of applied irrigation, average plant height, leaf area index (LAI), above-ground dry matter (ADM) and root density of wheat as influenced by irrigation water quality, soil texture and their interaction over three cropping seasons in Mymensingh, Bangladesh

\begin{tabular}{|c|c|c|c|c|c|c|c|c|}
\hline \multirow[t]{2}{*}{ Treatment } & \multirow{2}{*}{$\begin{array}{l}\text { Irrigation } \\
\quad(\mathrm{cm})\end{array}$} & \multirow{2}{*}{$\begin{array}{l}\text { Plant } \\
\text { height } \\
(\mathrm{cm})\end{array}$} & \multirow{2}{*}{$\begin{array}{c}\text { LAI at } 75 \\
\text { DAS }\end{array}$} & \multirow{2}{*}{$\begin{array}{l}\mathrm{ADM} \text { at } \\
75 \mathrm{DAS}\end{array}$} & \multicolumn{4}{|c|}{ Root density $\left(\mathrm{kg} \mathrm{m}^{-2}\right)$ at depth } \\
\hline & & & & & $\begin{array}{l}0-15 \\
(\mathrm{~cm})\end{array}$ & $\begin{array}{c}15-30 \\
(\mathrm{~cm})\end{array}$ & $\begin{array}{c}30-45 \\
(\mathrm{~cm})\end{array}$ & $\begin{array}{l}0-45 \\
(\mathrm{~cm})\end{array}$ \\
\hline & \multicolumn{8}{|c|}{ Irrigation } \\
\hline $\mathrm{I}_{1}(\mathrm{FW})$ & - & $80.5 \mathrm{a}$ & $1.84 \mathrm{a}$ & $3.3 \mathrm{a}$ & $0.44 \mathrm{a}$ & $0.11 \mathrm{a}$ & $0.04 \mathrm{a}$ & $0.58 \mathrm{a}$ \\
\hline $\mathrm{I}_{2}(\mathrm{WW})$ & - & $85.0 \mathrm{~b}$ & $2.92 b$ & $6.0 \mathrm{~b}$ & $0.31 \mathrm{~b}$ & $0.07 \mathrm{~b}$ & $0.04 \mathrm{a}$ & $0.42 b$ \\
\hline \multicolumn{9}{|c|}{ Soil texture } \\
\hline $\mathrm{T}_{1}$ & 22.7 & $79.1 \mathrm{a}$ & $1.72 \mathrm{a}$ & $3.6 \mathrm{~d}$ & $0.41 \mathrm{a}$ & $0.10 \mathrm{a}$ & $0.04 \mathrm{a}$ & $0.55 \mathrm{a}$ \\
\hline $\mathrm{T}_{2}$ & 20.7 & $84.2 b$ & $2.46 \mathrm{~b}$ & $4.6 b c$ & $0.39 \mathrm{ab}$ & $0.11 \mathrm{a}$ & $0.05 \mathrm{a}$ & $0.54 \mathrm{a}$ \\
\hline $\mathrm{T}_{3}$ & 18.2 & $84.6 b$ & $2.37 b$ & $5.2 \mathrm{ab}$ & $0.39 \mathrm{ab}$ & $0.09 \mathrm{a}$ & $0.04 \mathrm{a}$ & $0.52 \mathrm{ab}$ \\
\hline $\mathrm{T}_{4}$ & 15.0 & $82.9 \mathrm{~b}$ & $2.61 b$ & $5.5 \mathrm{a}$ & $0.35 \mathrm{bc}$ & $0.08 \mathrm{ab}$ & $0.04 \mathrm{a}$ & $0.48 b$ \\
\hline $\mathrm{T}_{5}$ & 13.8 & $82.9 \mathrm{~b}$ & $2.74 \mathrm{~b}$ & $4.3 \mathrm{~cd}$ & $0.31 \mathrm{c}$ & $0.06 \mathrm{~b}$ & $0.04 \mathrm{a}$ & $0.41 \mathrm{c}$ \\
\hline \multicolumn{9}{|c|}{ Irrigation $\times$ Soil texture } \\
\hline $\mathrm{I}_{1} \mathrm{~T}_{1}$ & 22.7 & $75.7 \mathrm{e}$ & $2.3 \mathrm{bc}$ & $1.9 \mathrm{f}$ & $0.46 \mathrm{ab}$ & $0.13 a$ & $0.04 \mathrm{a}$ & $0.63 b c$ \\
\hline $\mathrm{I}_{1} \mathrm{~T}_{2}$ & 20.7 & $78.7 \mathrm{de}$ & $3.6 \mathrm{c}$ & $2.5 \mathrm{ef}$ & $0.52 \mathrm{a}$ & $0.13 \mathrm{a}$ & $0.04 \mathrm{a}$ & $0.69 \mathrm{c}$ \\
\hline $\mathrm{I}_{1} \mathrm{~T}_{3}$ & 18.2 & $82.2 \mathrm{bcd}$ & $2.6 b c$ & $4.3 \mathrm{~cd}$ & $0.45 \mathrm{bc}$ & $0.1 \mathrm{ab}$ & $0.04 \mathrm{a}$ & $0.58 \mathrm{ab}$ \\
\hline $\mathrm{I}_{1} \mathrm{~T}_{4}$ & 15.0 & $80.7 \mathrm{~cd}$ & $3.4 \mathrm{c}$ & $3.6 \mathrm{de}$ & $0.43 \mathrm{bc}$ & $0.1 \mathrm{ab}$ & $0.04 \mathrm{a}$ & $0.58 \mathrm{ab}$ \\
\hline $\mathrm{I}_{1} \mathrm{~T}_{5}$ & 13.8 & $85.1 \mathrm{abc}$ & $2.8 \mathrm{c}$ & $3.9 \mathrm{~d}$ & $0.31 \mathrm{de}$ & $0.06 \mathrm{~b}$ & $0.04 a$ & $0.42 \mathrm{a}$ \\
\hline $\mathrm{I}_{2} \mathrm{~T}_{1}$ & 22.7 & $82.6 \mathrm{bcd}$ & $1.2 \mathrm{a}$ & $5.2 \mathrm{~cd}$ & $0.35 \mathrm{bcd}$ & $0.08 \mathrm{ab}$ & $0.05 a$ & $0.48 \mathrm{ab}$ \\
\hline
\end{tabular}




$\begin{array}{lllllllll}\mathrm{I}_{2} \mathrm{~T}_{2} & 20.7 & 89.7 \mathrm{a} & 1.3 \mathrm{a} & 6.8 \mathrm{ab} & 0.26 \mathrm{e} & 0.08 \mathrm{ab} & 0.06 \mathrm{a} & 0.39 \mathrm{a} \\ \mathrm{I}_{2} \mathrm{~T}_{3} & 18.2 & 86.9 \mathrm{ab} & 2.2 \mathrm{bc} & 6.0 \mathrm{bc} & 0.32 \mathrm{bcde} & 0.09 \mathrm{ab} & 0.05 \mathrm{a} & 0.46 \mathrm{ab} \\ \mathrm{I}_{2} \mathrm{~T}_{4} & 15.0 & 85 \mathrm{bc} & 1.9 \mathrm{ab} & 7.3 \mathrm{a} & 0.27 \mathrm{e} & 0.07 \mathrm{~b} & 0.04 \mathrm{a} & 0.38 \mathrm{a} \\ \mathrm{I}_{2} \mathrm{~T}_{5} & 13.8 & 80.7 \mathrm{cde} & 2.7 \mathrm{c} & 4.8 \mathrm{~cd} & 0.32 \mathrm{cde} & 0.06 \mathrm{~b} & 0.03 \mathrm{a} & 0.41 \mathrm{a}\end{array}$

Common letter(s) within the same column do not differ significantly at $5 \%$ level of significance. D.f. regarding the split-plot design: Erro1 = 2; Interaction Factor 1 x Factor 2: 4; Error 2: 16. Total 53-mm rainfall $(41 \mathrm{~mm}$ in December and $12 \mathrm{~mm}$ in February) occurred in 2010-11 cropping season; no rainfall occurred over crop cycles in the two previous years.

Addition of even a small quantity of amendment (as in $\mathrm{T}_{2}$ ) remarkably improved soil-water retention; the rate of this improvement, however, decreased with further increase in amendment. Reduced evaporation rate due to higher water-holding capacity of clay than sand also helped increasing soil-water content in the amended treatments. The water content at field capacity increased with increasing clay content of the treatments following a strong linear relation $\left(r^{2}=0.93\right)$. The amendment helped increasing the field capacity by $78 \%, 80 \%$ and $91 \%$ in treatment $\mathrm{T}_{2}$, $\mathrm{T}_{3}$ and $\mathrm{T}_{4}$, respectively compared to $\mathrm{T}_{1}$ (Mojid et al., 2012b). The WW contained N, P and $\mathrm{K}$ at concentration of $17.5 \mathrm{mg} \mathrm{L}^{-1}, 3.7 \mathrm{mg} \mathrm{L}^{-1}$ and $10.3 \mathrm{mg} \mathrm{L}^{-1}$, respectively and added these nutrients to the irrigated soils and elevated their fertility. Increased nutrients (e.g., N, P, K) in WW compared to FW improved fertility of the soils under irrigation with WW and enhanced vegetative growth of wheat with the consequent increase in plant height, LAI and ADM of the crop (Table 3). However, the elevated quantity of available water associated with more nutrient retention in finer-textured soils generally enhanced crop growth attributes more compared to that of the coarsetextured soils.

\subsection{Yield Attributes of Wheat}

Irrigation water quality influenced significantly the yield attributes of wheat, such as spike density, spike length, spikelets per spike and grains per spike, with WW producing more spikes per unit area, longer spike, more spikelets per spike and more grains per spike (Table 4). The weight of 1000 grains of wheat remained unaffected by irrigation water quality. Soil texture exerted significant influence on spikes per square meter and spike length for most treatments and on spikelets per spike and 1000-grain weight for a few treatments; grains per spike remained unaffected by the soil textures. Table 4 demonstrates that all the yield attributes improved as texture of the soils became finer. Poor nutrient availability and water-retention capacity of loamy sand $\left(T_{1}\right)$ and sandy loam $\left(T_{2}\right)$ compared to the other soil textures suppressed the yield attributes in these treatments.

Table 4. Quantity of applied irrigation, average number of spikes per square meter, spike length, spikelets per spike, grains per spike and 1000-grain weight of wheat as influenced by irrigation water quality, soil texture and their interaction over three cropping seasons in Mymensingh, Bangladesh

\begin{tabular}{|c|c|c|c|c|c|c|}
\hline Treatment & $\begin{array}{l}\text { Irrigation } \\
(\mathrm{cm})\end{array}$ & $\begin{array}{l}\text { Spikes } \\
\left(\mathrm{m}^{-2}\right)\end{array}$ & $\begin{array}{l}\text { Spike length } \\
(\mathrm{cm})\end{array}$ & $\begin{array}{l}\text { Spikelets } \\
\left(\text { snike }^{-1}\right)\end{array}$ & $\begin{array}{l}\text { Grains } \\
\left(\text { snike }^{-1}\right)\end{array}$ & $\begin{array}{l}\text { 1000-grain } \\
\text { weight (g) }\end{array}$ \\
\hline & \multicolumn{6}{|l|}{ Irrigation } \\
\hline $\mathrm{I}_{1}(\mathrm{FW})$ & - & $208.5 \mathrm{a}$ & $12.9 \mathrm{a}$ & $15.7 \mathrm{a}$ & $36.8 \mathrm{a}$ & $47.9 \mathrm{a}$ \\
\hline \multirow[t]{2}{*}{$\mathrm{I}_{2}(\mathrm{WW})$} & - & $267.3 \mathrm{~b}$ & $13.5 b$ & $16.8 \mathrm{~b}$ & $39.2 \mathrm{~b}$ & $47.4 \mathrm{a}$ \\
\hline & \multicolumn{6}{|c|}{ Soil texture } \\
\hline $\mathrm{T}_{1}$ & 22.7 & $199.2 \mathrm{c}$ & $12.7 b$ & $15.1 \mathrm{~b}$ & $36.3 a$ & $46.6 \mathrm{~b}$ \\
\hline $\mathrm{T}_{2}$ & 20.7 & $243.2 \mathrm{ab}$ & $13.2 \mathrm{ab}$ & $16.0 \mathrm{ab}$ & $37.1 \mathrm{a}$ & $46.2 b$ \\
\hline $\mathrm{T}_{3}$ & 18.2 & $235.8 b$ & $13.5 \mathrm{a}$ & $16.7 \mathrm{a}$ & $38.9 \mathrm{a}$ & $49.8 \mathrm{a}$ \\
\hline $\mathrm{T}_{4}$ & 15.0 & $248.6 \mathrm{ab}$ & $13.2 \mathrm{ab}$ & $16.6 \mathrm{a}$ & $39.1 \mathrm{a}$ & $47.5 b$ \\
\hline $\mathrm{T}_{5}$ & 13.8 & $262.6 \mathrm{a}$ & $13.5 \mathrm{a}$ & $16.8 \mathrm{a}$ & $38.7 \mathrm{a}$ & $47.9 \mathrm{ab}$ \\
\hline \multicolumn{7}{|c|}{ Irrigation $\times$ Soil texture } \\
\hline $\mathrm{I}_{1} \mathrm{~T}_{1}$ & 22.7 & $177.0 \mathrm{a}$ & $12.3 \mathrm{ab}$ & $14.6 \mathrm{c}$ & 33.6de & $44.5 \mathrm{a}$ \\
\hline $\mathrm{I}_{1} \mathrm{~T}_{2}$ & 20.7 & $195.9 \mathrm{ab}$ & $12.5 \mathrm{ab}$ & $14.2 \mathrm{c}$ & $33.1 \mathrm{e}$ & $46.5 \mathrm{abc}$ \\
\hline $\mathrm{I}_{1} \mathrm{~T}_{3}$ & 18.2 & $221.7 \mathrm{bcd}$ & $13.3 b c$ & $17.3 \mathrm{ab}$ & 39.4abc & $49.4 b c$ \\
\hline $\mathrm{I}_{1} \mathrm{~T}_{4}$ & 15.0 & $199.2 \mathrm{ab}$ & $12.8 \mathrm{ab}$ & $15.4 \mathrm{bc}$ & $36.4 \mathrm{bcde}$ & $49.1 \mathrm{bc}$ \\
\hline $\mathrm{I}_{1} \mathrm{~T}_{5}$ & 13.8 & $248.6 \mathrm{cde}$ & $13.8 \mathrm{c}$ & $17.3 \mathrm{ab}$ & $41.5 \mathrm{ab}$ & $47.3 \mathrm{abc}$ \\
\hline $\mathrm{I}_{2} \mathrm{~T}_{1}$ & 22.7 & $221.3 \mathrm{abc}$ & 13.0abc & $15.6 \mathrm{bc}$ & $39.0 \mathrm{abc}$ & $48.7 \mathrm{abc}$ \\
\hline
\end{tabular}




\begin{tabular}{lllllll}
$\mathrm{I}_{2} \mathrm{~T}_{2}$ & 20.7 & $290.6 \mathrm{e}$ & $13.9 \mathrm{c}$ & $17.9 \mathrm{a}$ & $41.1 \mathrm{abc}$ & $46.0 \mathrm{ab}$ \\
$\mathrm{I}_{2} \mathrm{~T}_{3}$ & 18.2 & $249.9 \mathrm{cde}$ & $13.7 \mathrm{bc}$ & $16.2 \mathrm{abc}$ & $38.4 \mathrm{abcd}$ & $50.3 \mathrm{c}$ \\
$\mathrm{I}_{2} \mathrm{~T}_{4}$ & 15.0 & $298.0 \mathrm{e}$ & $13.6 \mathrm{bc}$ & $17.9 \mathrm{a}$ & $41.9 \mathrm{a}$ & $45.9 \mathrm{ab}$ \\
$\mathrm{I}_{2} \mathrm{~T}_{5}$ & 13.8 & $276.6 \mathrm{de}$ & $13.1 \mathrm{abc}$ & $16.4 \mathrm{abc}$ & $35.9 \mathrm{cde}$ & $48.6 \mathrm{abc}$ \\
\hline
\end{tabular}

Common letter(s) within the same column do not differ significantly at $5 \%$ level of significance. D.f. regarding the split-plot design: Erro1 = 2; Interaction Factor 1 x Factor 2: 4; Error 2: 16.

The interaction effects of irrigation water quality and soil texture on the yield attributes of wheat were significant for most treatment combinations (Table 4). FW in combination with loamy sand $\left(\mathrm{I}_{1} \mathrm{~T}_{1}\right)$ and sandy loam $\left(\mathrm{I}_{1} \mathrm{~T}_{2}\right)$ produced the poorest yield attributes, while WW in combination with loam-2 $\left(\mathrm{I}_{2} \mathrm{~T}_{4}\right)$ produced the most improved spikes per square meter, spikelets per spike and grains per spike. The longest spike was obtained in $\mathrm{I}_{2} \mathrm{~T}_{2}$ treatment combination, which produced statistically similar spike length to $\mathrm{I}_{2} \mathrm{~T}_{3}, \mathrm{I}_{2} \mathrm{~T}_{4}$ and $\mathrm{I}_{2} \mathrm{~T}_{5}$ treatment combinations. The 1000 -grain weight was the highest in $\mathrm{I}_{2} \mathrm{~T}_{3}$. WW in combination with the five soil textural treatments provided more improved yield attributes of wheat compared to FW in combination with the soil treatment, further implying that WW contributed more in improving the yield attributes compared to FW. Table 4 also demonstrates that the yield attributes generally continued increasing as the texture of the soil became finer under irrigation with FW; however, such trend was not evident under irrigation with WW. These results revealed that under FW irrigation and recommended fertilizer doses the overall fertility levels of the soil textural treatments did not reach their possible maximum limits in all treatments for fertilizing wheat. Although irrigation with WW contributed increasingly on the growth attributes of wheat as soil texture became finer, it did not contributed in the same way on the yield attributes.

\subsection{Yield and Harvest Index of Wheat}

As given in Table 5, irrigation water quality influenced significantly wheat traits like grain yield, straw yield and biomass yield; harvest index remained unaffected. Irrigation with WW improved these wheat traits irrespective of soil textural differences. The effect of soil texture was statistically similar on these traits of the crop except treatment $T_{1}$ (loamy sand, Table 1), which produced significantly lower grain, straw and biomass yields compared to the other treatments $\left(T_{2}-T_{5}\right)$. However, these three yield measures of wheat increased with the increase of clay content in the treatments. The field soil $\left(\mathrm{T}_{5}\right)$ contained four times higher organic carbon $(0.85 \%)$ than the control $\left(\mathrm{T}_{1}\right)$. Consequently, the amendment considerably elevated organic carbon (hence organic matter) in treatments $\mathrm{T}_{2}$, $T_{3}$ and $T_{4}$ compared to $T_{1}$. Poor yields in $T_{1}$ could be explained by lower organic matter, other nutrients ( $N, P$ and $\mathrm{K})$ and water contents in this treatment. Reduced wheat yield under lower soil-water content was also reported by Simsek et al. (2005).

Table 5. Quantity of applied irrigation, average grain, straw and biomass yields, harvest index (HI), and water productivity resulting from grain $\left(\mathrm{WP}_{\mathrm{g}}\right)$ and biomass yields $\left(\mathrm{WP}_{\mathrm{b}}\right)$ as influenced by irrigation water quality, soil texture and their interaction over three cropping seasons in Mymensingh, Bangladesh

\begin{tabular}{|c|c|c|c|c|c|c|c|}
\hline Treatment & $\begin{array}{l}\text { Irrigation } \\
(\mathrm{cm})\end{array}$ & $\begin{array}{c}\text { Grain yield } \\
\left(\mathrm{t} \mathrm{ha}^{-1}\right)\end{array}$ & $\begin{array}{l}\text { Straw yield } \\
\left(\mathrm{t} \mathrm{ha}^{-1}\right)\end{array}$ & $\begin{array}{l}\text { Biomass yield } \\
\left(\mathrm{t} \mathrm{ha}^{-1}\right)\end{array}$ & $\begin{array}{l}\mathrm{HI} \\
(-)\end{array}$ & $\begin{array}{c}\mathrm{WP}_{\mathrm{g}} \\
\left(\mathrm{kg} \mathrm{m}^{-3}\right)\end{array}$ & $\begin{array}{c}\mathrm{WP}_{\mathrm{b}} \\
\left(\mathrm{kg} \mathrm{m}^{-3}\right)\end{array}$ \\
\hline \multicolumn{8}{|c|}{ Irrigation } \\
\hline $\mathrm{I}_{1}(\mathrm{FW})$ & - & $2.88 \mathrm{a}$ & $3.61 \mathrm{a}$ & $6.48 \mathrm{a}$ & $0.44 a$ & $1.25 \mathrm{a}$ & $2.84 a$ \\
\hline $\mathrm{I}_{2}(\mathrm{WW})$ & - & $4.12 b$ & $4.83 b$ & $8.95 b$ & $0.46 \mathrm{a}$ & $2.28 b$ & $4.99 b$ \\
\hline \multicolumn{8}{|c|}{ Soil texture } \\
\hline $\mathrm{T}_{1}$ & 22.7 & $2.70 \mathrm{a}$ & $3.31 \mathrm{a}$ & $6.02 \mathrm{a}$ & $0.44 \mathrm{a}$ & $1.20 \mathrm{c}$ & $2.75 \mathrm{a}$ \\
\hline $\mathrm{T}_{2}$ & 20.7 & $3.66 \mathrm{~b}$ & $4.44 b$ & $8.10 \mathrm{~b}$ & $0.44 \mathrm{a}$ & $1.84 \mathrm{ab}$ & $4.05 b$ \\
\hline $\mathrm{T}_{3}$ & 18.2 & $3.47 \mathrm{~b}$ & $4.16 \mathrm{~b}$ & $7.62 b$ & $0.45 \mathrm{a}$ & $1.68 b$ & $3.78 b$ \\
\hline $\mathrm{T}_{4}$ & 15.0 & $3.72 b$ & $4.54 \mathrm{~b}$ & $8.26 b$ & $0.46 \mathrm{a}$ & $1.99 \mathrm{ab}$ & $4.45 b$ \\
\hline $\mathrm{T}_{5}$ & 13.8 & $3.94 \mathrm{~b}$ & $4.64 \mathrm{~b}$ & $8.59 \mathrm{~b}$ & $0.46 \mathrm{a}$ & $2.11 \mathrm{a}$ & $4.55 \mathrm{~b}$ \\
\hline \multicolumn{8}{|c|}{ Irrigation $\times$ Soil texture } \\
\hline $\mathrm{I}_{1} \mathrm{~T}_{1}$ & 22.7 & $2.0 \mathrm{f}$ & $2.8 \mathrm{f}$ & $4.7 \mathrm{e}$ & $0.42 \mathrm{ab}$ & $0.8 \mathrm{f}$ & $1.94 \mathrm{f}$ \\
\hline $\mathrm{I}_{1} \mathrm{~T}_{2}$ & 20.7 & $2.3 \mathrm{ef}$ & $3.3 \mathrm{ef}$ & 5.6de & $0.41 b$ & $0.9 \mathrm{ef}$ & $2.28 \mathrm{f}$ \\
\hline $\mathrm{I}_{1} \mathrm{~T}_{3}$ & 18.2 & $3.1 \mathrm{de}$ & $4.0 \mathrm{cde}$ & $7.0 \mathrm{~cd}$ & $0.44 \mathrm{ab}$ & $1.3 \mathrm{de}$ & $3.04 \mathrm{def}$ \\
\hline $\mathrm{I}_{1} \mathrm{~T}_{4}$ & 15.0 & $2.9 \mathrm{def}$ & $3.4 \mathrm{def}$ & $6.3 \mathrm{de}$ & $0.46 a b$ & $1.2 \mathrm{ef}$ & $2.79 \mathrm{ef}$ \\
\hline
\end{tabular}




\begin{tabular}{llllllll}
$\mathrm{I}_{1} \mathrm{~T}_{5}$ & 13.8 & $4.2 \mathrm{abc}$ & $4.6 \mathrm{bcd}$ & $8.7 \mathrm{bc}$ & $0.47 \mathrm{a}$ & $2.0 \mathrm{~cd}$ & $4.16 \mathrm{bcd}$ \\
$\mathrm{I}_{2} \mathrm{~T}_{1}$ & 22.7 & $3.4 \mathrm{cde}$ & $3.9 \mathrm{cde}$ & $7.3 \mathrm{~cd}$ & $0.47 \mathrm{ab}$ & $1.6 \mathrm{de}$ & $3.55 \mathrm{cde}$ \\
$\mathrm{I}_{2} \mathrm{~T}_{2}$ & 20.7 & $5.0 \mathrm{a}$ & $5.6 \mathrm{ab}$ & $10.6 \mathrm{a}$ & $0.47 \mathrm{ab}$ & $2.8 \mathrm{a}$ & $5.82 \mathrm{a}$ \\
$\mathrm{I}_{2} \mathrm{~T}_{3}$ & 18.2 & $3.8 \mathrm{bcd}$ & $4.4 \mathrm{~cd}$ & $8.2 \mathrm{c}$ & $0.47 \mathrm{ab}$ & $2.0 \mathrm{~cd}$ & $4.51 \mathrm{bc}$ \\
$\mathrm{I}_{2} \mathrm{~T}_{4}$ & 15.0 & $4.5 \mathrm{ab}$ & $4.7 \mathrm{abc}$ & $10.2 \mathrm{ab}$ & $0.45 \mathrm{ab}$ & $2.7 \mathrm{ab}$ & $6.12 \mathrm{a}$ \\
$\mathrm{I}_{2} \mathrm{~T}_{5}$ & 13.8 & $3.7 \mathrm{bcd}$ & $5.6 \mathrm{a}$ & $8.4 \mathrm{bc}$ & $0.45 \mathrm{ab}$ & $2.2 \mathrm{bc}$ & $4.94 \mathrm{ab}$ \\
\hline
\end{tabular}

Common letter(s) within the same column do not differ significantly at $5 \%$ level of significance. D.f. regarding the split-plot design: Erro1 = 2; Interaction Factor 1 x Factor 2: 4; Error 2: 16.

The interaction effect of irrigation and soil texture under recommended fertilizer dose was more favorable for wheat yields (grain, straw and biomass yields) when irrigation was done with WW compared to irrigation with FW. Irrigation with WW produced greater grain, straw and biomass yields in the corresponding soil treatments when compared with irrigation with FW (Table 5). Harvest index, HI, remained mostly unaffected by the interaction effect of irrigation water quality and soil texture. Like yield attributes, FW in combination with loamy sand $\left(\mathrm{I}_{1} \mathrm{~T}_{1}\right)$ produced the lowest yields of wheat that were similar to the yields under the combination of FW and sandy loam $\left(\mathrm{I}_{1} \mathrm{~T}_{2}\right)$ but significantly lower than the yields of other treatment combinations. Treatments $\mathrm{T}_{3}, \mathrm{~T}_{4}$ and $\mathrm{T}_{5}$ produced statistically similar grain and straw yields under FW irrigation. Inadequate soil water along with reduced nutrient in $T_{1}$ retarded physiological processes in the plants and consequently reduced the crop yields. Under FW irrigation, the grain, straw and biomass yields increased as the texture of the soil became finer except the treatment combination $I_{1} T_{4}$, which produced lower yields than the treatment combination $I_{1} T_{3}$. The enhanced vegetative growth in terms of plant height and number of tillers per plant in the amended treatments increased straw yield that, in turn, together with yield attributes, improved the biomass yield. The amendment, however, did not systematically influence the harvest index of wheat. Irrigation with FW in combination with recommended fertilizer dose produced the most improved yield of wheat in silt loam $\left(T_{5}\right)$, thus revealing that this soil texture is the most suitable for wheat cultivation under recommended fertilizer doze and irrigation with FW. The interaction effect of irrigation with WW and soil texture on the yields of wheat had no systematic trend with the texture of the soils except that the treatment combination $\mathrm{I}_{2} \mathrm{~T}_{1}$ produced the lowest yields, which were significantly lower than the yields of other treatment combinations. The highest grain yield was obtained in treatment combination $\mathrm{I}_{2} \mathrm{~T}_{2}$, straw yield in $\mathrm{I}_{2} \mathrm{~T}_{2}$ and $\mathrm{I}_{2} \mathrm{~T}_{5}$, and biomass yield in $\mathrm{I}_{2} \mathrm{~T}_{4}$. The enhanced vegetative growth due to increased soil-water content augmented straw yield, which, together with yield attributing characters, improved the biomass yield. Under WW irrigation, soil texture minimally influenced the HI of wheat. These results again revealed that, under FW irrigation and recommended fertilizer doses, the overall fertility levels of the soil textural treatments did not reach their maximum limits in all treatments for wheat growth, while the fertility levels under irrigation with WW might reach or even exceeded the maximum limits except in the most light-textured soil $\left(\mathrm{T}_{1}\right)$. These results are in agreement with the findings of Mojid et al. (2012c) who obtained suppressed grain yield of wheat when the applied irrigation comprised over 75\% WW and recommended fertilizer dose was applied.

\subsection{Water Productivity of Wheat}

Irrigation water quality influenced significantly water productivity of wheat related to grain and biomass yields, with WW providing significantly greater water productivity compared to FW (Table 5). Both water productivity data increased as soil texture became finer since the treatments with high clay content consumed small amount of water. Similar findings were reported by Ismail and Ozawa (2007). Particularly, treatments $T_{2}$ to $T_{5}$ saved $30 \%$ to $60 \%$ irrigation water compared to treatment $T_{1}$. Irrespective of water quality, loamy sand $\left(T_{1}\right)$ provided the least water productivities of wheat and silt loam $\left(\mathrm{T}_{5}\right)$ provided the greatest values. Both water productivities were significantly lower in $T_{1}$ treatment than in the other soil treatments. In terms of water productivity related to grain yield, treatment $T_{5}$ performed best; this performance was however statistically similar to that of $T_{4}$. In terms of water productivity related to biomass yield, the best-performing treatment was also $T_{5}$, whose performance was similar to that of treatments $T_{2}, T_{3}$ and $T_{4}$.

Soil texture exerted varying degrees of influence on the two water productivity data in different combinations of irrigation water quality and soil texture. WW in combination with soil textures provided higher water productivities related to both grain and biomass yields compared to the corresponding treatment combinations of $\mathrm{FW}$ and soil textures. Loamy sand $\left(T_{1}\right)$ in combination with irrigation with $\mathrm{FW}\left(\mathrm{I}_{1} \mathrm{~T}_{1}\right)$ produced the least water productivities, while silt loam $\left(\mathrm{T}_{5}\right)$ with FW irrigation $\left(\mathrm{I}_{1} \mathrm{~T}_{5}\right)$ produced the greatest water productivities. Under FW irrigation, both water productivity data increased as the texture of the soil became finer except treatment $T_{4}$, which provided statistically similar but lower water productivities compared to treatment $T_{3}$. The highest water productivity for 
grain production in $T_{5}$ revealed that wheat, cultivated under irrigation with $\mathrm{FW}$ in combination with the recommended fertilizer doses, most effectively utilized water in grain production. Thus, clay helped conserving soil water and nutrients by improving soil structure that contributed increasing growth and water productivity of wheat. The control treatment always provided the lowest water productivity since irrigation requirement and, hence, total water used in a plot increased with the decreasing clay content of the plot. Under WW irrigation, the treatment combination $\mathrm{I}_{2} \mathrm{~T}_{1}$ provided the least water productivities, which were significantly lower than that under the other treatment combinations. The treatment combination $\mathrm{I}_{2} \mathrm{~T}_{2}$ provided the most improved water productivity related to grain yield and $\mathrm{I}_{2} \mathrm{~T}_{4}$ provided such water productivity related to biomass yield. The interaction effects of irrigation with WW and soil texture did not reveal any systematic trend in relation to textural variations except the loamy sand $\left(T_{1}\right)$, which provided the least water productivity data.

\section{Conclusions}

Addition of small quantities of clay (2.4-4.0\%) through silt loam transformed loamy sand to sandy loam and loam. This amendment improved soil structure, reduced saturated hydraulic conductivity (by reducing the macro pores) of the soil, and increased soil-water and nutrient contents. Consequently, irrigation water quality contributed to wheat cultivation differently following soil texture. Soil-water and organic-matter contents of fine-textured soils were much higher than that of loamy sand. In terms of grain, straw and biomass yields, sandy loam and loam-2 performed the best with high water productivity followed by silt loam irrespective of irrigation water quality; loamy sand performed the least. The least water productivity was obtained in loamy sand while the amended soils could save $30 \%$ to $60 \%$ of irrigation water. Among the five soil textures, sandy loam and loam appeared the most suitable soil textures for wheat cultivation since they produced more grain and biomass yields compared to loamy sand. The results of this study thus provide information in selecting lands with suitable soil texture for wheat cultivation, specifically in alluvial plains where soil texture varies widely. However, the essence of this study is that amendment of lower quality coarse-textured soils by adding naturally available and inexpensive clay could improve crop productivity through better water regimes and higher nutrient content.

\section{Conflict of interest}

The authors declare that there is no conflict of interest.

\section{References}

Al-Omran, A. M., Falatah, A. M, Sheta, A. S., \& Al-Harbi, A. R. (2004). Clay deposits for water management of sandy soils. Arid Land Research and Management, 18, 171-183. https://doi.org/10.1080/15324980490280825

Al-Rashed, M. F., \& Sherif, M. M. (2000). Water resources in the GCC countries: An overview. Water Resources Management, 14, 59-75. https://doi.org/10.1023/A:1008127027743

Analytical Software. (2019). Statistix 10: Data Analysis Software for Researchers. Analytical Software 2105 Miller Landing Rd, Tallahassee, FL 32312, USA.

Biswas, S. K., \& Mojid, M. A. (2018). Changes in soil properties in response to irrigation of potato by urban wastewater. Communications in Soil Science and Plant Analysis, 49, 828-839. https://doi.org/10.1080/00103624.2018.1435684

Biswas, S. K., Mojid, M. A., \& Wyseure, G. C. L. (2017). Physicochemical properties of soil under wheat cultivation by irrigation with municipal wastewater in Bangladesh. Communications in Soil Science and Plant Analysis, 48, 1-10. https://doi.org/10.1080/00103624.2016.1253713

FAO (Food and Agriculture Organization). (1992). Wastewater treatment and use in agriculture. FAO Irrigation and Drainage Paper, 47, 16-17.

Feigin, A., Ravina, I., \& Shalhevet, J. (1990). Irrigation with Treated Sewage Effluent. Ecological Series, Springer Verlag, New York.

Kiziloglu, F. M., Turan, M., Sahin, U., Angin, I., Anapali, O., \& Okuroglu, M. (2007). Effects of wastewater irrigation on soil and cabbage-plant (Brassica olerecea var. capitate cv. yalova-1) chemical properties. Journal of Plant Nutrition and Soil Science, 170, 166-172. https://doi.org/10.1002/jpln.200621971

Li, Z. Z., Li, W. D., \& Li, W. L. (2004). Dry period irrigation and fertilizer application affect water use and yield of spring wheat in semi-arid regions. Agricultural Water Management, 65, 133-143. https://doi.org/10.1016/j.agwat.2003.07.007

Mojid, M. A., \& Wyseure, G. C. L. (2013). Implications of municipal wastewater irrigation on soil health from a 
study in Bangladesh. Soil Use and Management, 29, 384-396. https://doi.org/10.1111/sum.12056

Mojid, M. A., Biswas, S. K., \& Wyseure, G. C. L. (2012c). Interaction effects of irrigation by municipal wastewater and inorganic fertilisers on wheat cultivation in Bangladesh. Field Crops Research, 134, 200-207. https://doi.org/10.1016/j.fcr.2012.06.010

Mojid, M. A., Mustafa, S. M. T., \& Wyseure, G. C. L. (2009). Growth, yield and water use efficiency of wheat in silt loam-amended loamy sand. Journal of the Bangladesh Agricultural University, 7, 403-410.

Mojid, M. A., Wyseure, G. C. L., \& Biswas, S. K. (2012a). Requirement of nitrogen, phosphorus and potassium fertilizers for wheat cultivation under irrigation by municipal wastewater. Journal of Soil Science and Plant Nutrition, 12, 655-665. http://dx.doi.org/10.4067/S0718-95162012005000023

Mojid, M. A., Wyseure, G. C. L., Biswas, S. K., \& Hossain, A. B. M. Z. (2010). Farmers' perceptions and knowledge in using wastewater for irrigation at twelve peri-urban areas and two sugar mill areas in Bangladesh. Agricultural Water Management, 98, 79-86. https://doi.org/10.1016/j.agwat.2010.07.015

Mojid, M. A., Wyseure, G. C., \& Mustafa, S. M. T. (2012b). Water use efficiency and productivity of wheat as a function of clay amendment. Environmental Control in Biology, 50, 347-362. https://doi.org/10.2525/ecb.50.347

Rahman, M. A., Ahmed, T., \& Mojid, M. A. (2020). Coupled irrigation-drainage management practice for HYV rice cultivation with saline-irrigation water: evidence from lysimeter experiment. Agricultural Science, 2, 95-95. https://doi.org/10.30560/as.v2n1p95

Simsek, M., Tonkaz, T., Kacira, M., Comlekcioglu, N., \& Dogan, Z. (2005). The effect of different irrigation regimes on cucumber (Cucumbis sativas L.) yield and yield characteristics under open field conditions. Agricultural Water Management, 73, 173-191. https://doi.org/10.1016/j.agwat.2004.10.013

Tabriz, S. S., Mojid, M. A., \& Wyseure, G. C. L. (2011). Irrigation suitability of North Bengal Sugar Mill's effluent and its impact on soil properties. Journal of the Bangladesh Agricultural University, 9. https://doi.org/10.3329/jbau.v9i2.11042

US Environmental Protection Agency. (1992). Guidelines for water reuse, Washington DC, US EPA.

Van Rooijen, D. J., Turral, H., \& Wade Biggs, T. (2005). Sponge city: water balance of mega-city water use and wastewater use in Hyderabad, India. Irrigation and Drainage: The journal of the International Commission on Irrigation and Drainage, 54(S1), S81-S91. https://doi.org/10.1002/ird.188

van Wambeke, A. (1992). Soils of the Tropics - Properties and Appraisal. McGraw Hill, Inc., New York, USA.

Virto, I., Bescansa, P., Imaz, M. J., \& Enrique, A. (2006). Soil quality under food processing wastewater irrigation in semi-arid land, northern Spain: aggregation and organic matter fractions. Journal of Soil and Water Conservation, 61, 398-407.

Wang, H., Tan, T. K., \& Schotzko, R. T. (2007). Interaction of potato production systems and the environment: a case of wastewater irrigation in central Washington. Waste Management and Research, 25, 14-23. https://doi.org/10.1177/0734242X07066337

\section{Copyrights}

Copyright for this article is retained by the author(s), with first publication rights granted to the journal.

This is an open-access article distributed under the terms and conditions of the Creative Commons Attribution license (http://creativecommons.org/licenses/by/4.0/). 